\title{
Employee attitudes to work safety in Poland's coal mining companies
}

\author{
by K. Tobór-Osadnik*, M. Wyganowska*, and A. Manowska*
}

\section{Synopsis}

The behaviour of employees is an essential issue in the field of occupational health and safety. Safe behaviour is to a large extent determined by, apart from motivation and preventive actions, an employee's attitude towards hazard. Thus, attention should be given to defining employees' attitudes, and following that, to the possibility of correcting and shaping these attitudes in relation to hazard and obeying occupational health and safety regulations. The authors have focused on the analysis of employee attitudes to health and safety regulations in Polish coal mining companies, taking into consideration earlier research on the behaviour of selected employees. The paper presents the methods used to identify Z-type (passive) behaviour. Next, this behaviour is analysed to identify differences between a Z-type employee (enslaved) and other employees. To conclude, the paper presents a list of possible motivational tools that may be used to encourage occupational health and safety in Z-type employees.

\section{Keywords}

coal mining, safety, employee attitudes.

\section{Introduction}

The technical state of equipment and conditions in the workplace greatly influence occupational safety. However, the deciding factor influencing the rate of accidents in the workplace is the frequency with which employees practise risky behaviour. Factors such as the social conditioning of conduct and motivation for organizing safe work conditions have been included in the notion of creating a positive culture of work safety. This notion has been approved as one of the main goals in management (Studenski, 1996).

Safe behaviour is to a large extent, apart from motivation and preventive actions, determined by an employee's attitude towards hazard. All actions undertaken in the field of occupational health and safety, including training, motivational systems, or imitation of behaviour resulting from a high culture of occupational safety in a given work environment, will not bring about the desire effects if workers have an inappropriate attitude towards occupational health and safety regulations.

An essential issue in the field of occupational health and safety is employee behaviour. According to statistical data
(Najmiec, 2003), almost half of all workrelated accidents result from incorrect or inappropriate employee behaviour and an improper attitude towards safety in the work environment. This refers not only to the attitude towards workplace hazards, but also to attitudes towards following health and safety regulations and the notion of workplace safety. Hence attention should be given to defining the attitudes of employees, and to the possibility of correcting and shaping these attitudes in relation to the notion of hazard and obeying occupational health and safety regulations. Taking into account the arguments above and previous research conducted in the area of freelance professions (expert creditors, accountants) (Tobór-Osadnik et al., 2013), corporations, metallurgy and mining companies (Tobór-Osadnik and Wyganowska, 2012) on defining selected employees' attitudes, the authors decided to address the problem of employee attitudes towards occupational health and safety in coal mining companies.

Previous research indicates that a significant number of workers present a passive attitude towards work, expecting full care from what is widely understood as 'the authorities', unwilling to undertake any action in order to change their situation (TobórOsadnik and Wyganowska, 2012) in any facet of their work life. This type is referred to as an 'enslaved worker' - a so-called Z-type personality (Korach, 2009). This syndrome, in various degrees of intensity, can be traced back to imperfections in the management systems in mining companies, mistakes committed in the process of political transformation, as well as to the ongoing process of

* Faculty of Mining and Geology, The Silesian University of Technology, Gliwice, Poland.

(C) The Southern African Institute of Mining and Metallurgy, 2017. ISSN 2225-6253. Paper received oct. 2015; revised paper received Jul. 2016. 


\section{Employee attitudes to work safety in Poland's coal mining companies}

strengthening procedures in many areas of company activities, which may lead to a decline in creativity, a sense of co-responsibility and self-control among some workers.

An interesting fact is that an attitude such as this occurs among workers raised or even born in Poland following the changes in the political system in 1989. These workers, similarly to their peers in other countries, display a syndrome of learned helplessness in the professional environment (Moczydłowska, 2005; Coutu, 2002). This probably results from the Polish education system. It often refers to individuals as having enormous potential and development possibilities, but at the same time unwilling to change their situation. These people expect full control and actions in accordance with patterns ('fill in the test', 'follow the procedure') (Harvey, 2009; Douglas and Martinko, 2001; Martinko et al., 2005). Such attitudes are strengthened in corporations with a strong hierarchy and an autocratic management style. Large coal mining corporations belong to this category.

Management effectiveness or adherence to occupational health and safety (OHS) regulations tend to be weakened when Z-type attitudes dominate in a work team and become the behavioural norm for the majority because other employees, observing no reaction to the behaviour of a Ztype worker, may adopt a similar attitude (Muethel and Hoegl, 2010).

\section{Description of employees' studied attitudes}

Employee attitudes have been widely characterized in the works of Tobór-Osadnik and Wyganowska (Tobór-Osadnik and Wyganowska, 2007, 2011; Tobór-Osadnik, 2012; TobórOsadnik, Kabalski, and Wyganowska, 2013). The studies show that employee attitudes do not depend on age or duration of employment, but are presented by individuals displaying a syndrome of 'learned helplessness' in their professional environment (Moczydłowska, 2005). Such individuals expect full control and pattern-following ('fill in the test', 'follow the procedure') (Harvey, 2009). Such attitudes are strengthened in organizations with a strong hierarchy and an autocratic management style. Arnott emphasizes that the strong culture of such organizations is reflected in the hierarchical structures based on following procedures, full control, and normativity (Yildiz, 2014). Studies on such behaviour in Polish companies were conducted by Grzywacz and Ochinowski (2003), who also demonstrated the existence of this phenomenon in the organizations they studied. Employee engagement in an organization's activities was also analysed by Macey and Schneider (2008).

Aspects of employee engagement in the organization's activities described by Macey and Schneider correlate with the traits (factors) of a Z-type worker determined by Korach (2009):

$$
\begin{aligned}
& \text { - Factor 'S' - slavery } \\
& \text { - Factor 'M' - martyrdom } \\
& >\text { Factor 'E' - egotism (Figure 1). }
\end{aligned}
$$

Factor ' $\mathrm{S}$ ' determines the degree of dependence upon the system displayed by the individual. It denotes an enslaved attitude, displaying an 'it must be so' character.
Factor ' $\mathrm{M}$ ' is a measure of an ingrained sense of injustice and oppression. Such an attitude is characterized by excessive suspicion, putting blame on others, insane claims.

Factor ' $E$ ' is a measure of the 'egotistic attitude' in an organization. When this factor is intensified in an employee, it shows in an attitude of unwillingness to take responsibility for the fate of others. This dimension is particularly dangerous in relation to attitudes towards $\mathrm{OHS}$ regulations at work (Tobór-Osadnik, Kabalski, and Wyganowska, 2013).

As an employee cannot be assigned to one type only, it is possible to determine only the dominating type. Thus, while studying these three assumed dimensions (factors) in the Ztype worker, we can determine a distance to each of the factors, treating them as a measure of the dominance of individual factors in the employee's general attitude.

On the basis of such assumptions the authors developed a tool (study questionnaire) to measure the intensity of S, M, and $\mathrm{E}$ traits in the Z-type worker. Each question was graphed from a decided lack of a particular trait to the strongest intensity of the trait. The questions included various areas of professional and personal life to exclude accidental answers or attempts at positive self-creation.

The enslaved attitude as such is not detrimental towards workplace safety. Appropriate management and choice of tasks for such an employee will ensure a correct attitude towards OHS. Blanchard (2007), the originator of the concept of situational management, recommends a style of instruction management in such a situation - creating clearly defined goals, a full action plan, and controlling its realization. Identification of such employees' attitudes allows an effective manager to control all subordinates in such a way as to realize intended goals, including those in the field of occupational health and safety.

\section{Research methodology}

In order to identify the attitude of a Z-type worker towards OHS regulations, a survey was conducted involving three of the largest Polish coal mining companies: KHW SA, KW SA, and JSW SA.

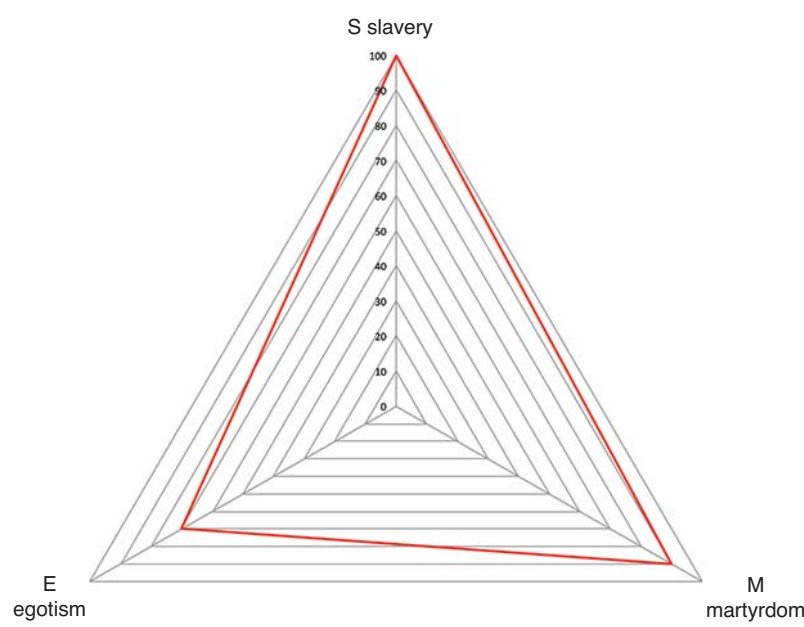

Figure 1-Distance to factors 'S', 'M', 'E' as a measure for a description of a 'Z'-type worker (Tobór-Osadnik, 2012) 


\section{Employee attitudes to work safety in Poland's coal mining companies}

Selecting the appropriate sample size is an important issue in employing surveys as a tool, as the results from the sample should reflect the entire population of which the sample is a part. Equation [1] can be used to determine the minimum sample size with a predefined level of precision:

$$
n=\frac{\hat{s}^{2} \cdot t_{\alpha}^{2}}{e^{2}}
$$

where

$\hat{S}^{2}$ is the variance

$t_{\alpha}^{2}$ is the value read off from Student's $t$ distribution tables for confidence level $1-\alpha$ $e^{2}$ is the maximum permissible estimate error.

Many different techniques, both direct and indirect, are used to select a random sample. For this investigation, a sample was drawn from the staff time-registration system. In order to comply with all the rules of probability, a randomselection algorithm was used to select workers to complete the survey. A sample selected in this manner is most likely to display the characteristics of the entire population.

In order to determine the minimum sample size, one must also specify, in advance, the level of confidence $1-\alpha$ and maximum (permissible) margin of error $e$. In the present survey, it was assumed that $95 \%$ of the results did not differ from the actual values, thus setting a significance level $\alpha=$ $10 \%$, resulting in a maximum margin of error also at $10 \%$ (value $t_{\alpha}$ was read from the Student's $t$-level distribution tables $1-{ }_{2}^{\alpha}$, as there is a two-tailed critical region). Equation [1] takes the following form:

$$
n=\frac{2.3897^{2}-1.9609^{2}}{0.1^{2}}=186
$$

It can be assumed from Equation [2] that the sample is representative at the level of $186 \pm 18$ correctly completed questionnaires. Thus, we may assume that in accordance with the assumptions the research met the requirements of sample size for further analysis.

The surveys were research-directed - that is, they were characterized by all participants being trained and directed as to how to correctly complete the questionnaire. In addition, support from a researcher was available throughout the entire time the questionnaire was being completed. The workers who participated in the study were diverse in terms of age, seniority, education, and position at work. Overall, 218 correctly completed questionnaires were collected and used for statistical analysis.

Respondents were differentiated according to age, length of employment, level of education, and work position. The minimum size of the research sample was determined using an independent simple selection:

To estimate the number of intervals the following formula was used (Stanisławek, 2010):

$$
k=1+3.3 \cdot \log _{10} n
$$

where $k$ is the number of intervals and $n$ is the size of the survey sample.

$$
1+3.3 \cdot \log _{10} 218=6.6
$$

Seven variability intervals were assumed for further research. The ranges of the intervals were determined on the basis of the mathematical dependency (Starzyńska, 2009):

$$
h=\frac{x_{\max }-x_{\min }}{k}
$$

where $h$ is the range of the interval.

In this manner seven variability intervals were estimated and determined for further analyses (Table I).

The percentage distribution of individual respondents in the intervals is shown in Figure 2.

A comparison of responses to those of the assumed pattern (no evidence of traits of Z-type employee) was used to identify employee attitudes. The resulting differences in observed values, or dispersion, were used for further analyses, in which the larger the value of dispersion, the more the value for each observation deviated from the expected pattern (Aczel, 2010).

Thus, in order to illustrate the dispersion of employee attitudes in relation to the pattern, the Mahalanobis distance was used - the distance between two points in $n$-dimensional space, which varies the contribution of individual components and uses the correlation between them. This technique is used in statistics in determining the similarity between the unknown random variable and the variable from the known set (standard) (Statistica, 2010).

Studying the correlation between unknown random variables $(x)$ for workers involved in the study, the similarity (i) of each variable was compared to variable $\mu$ of the model, taking into account the information on the variances in the $i$ variables and the correlations between them. The Mahalanobis distance is equal to the Euclidean distance when each $i$ variables are not correlated, which is expressed by Equation [6] (Aczel, 2010):

$$
d_{m}(x, \mu)=\sqrt{\left(x_{1}-\mu_{1}\right)^{2}+\cdots+\left(x_{n}-\mu_{n}\right)^{2}}
$$

Table I

\section{Variability intervals}

\begin{tabular}{l|c|c}
\hline No traits & 0 & 2.714286 \\
Traits barely noticeable & 2.714286 & 5.428571 \\
Noticeable traits & 5.428571 & 8.142857 \\
Medium-significant traits & 8.142857 & 10.85714 \\
Significant traits & 10.85714 & 13.57143 \\
Essential traits & 13.57143 & 16.28571 \\
Strong traits & 16.28571 & 19
\end{tabular}

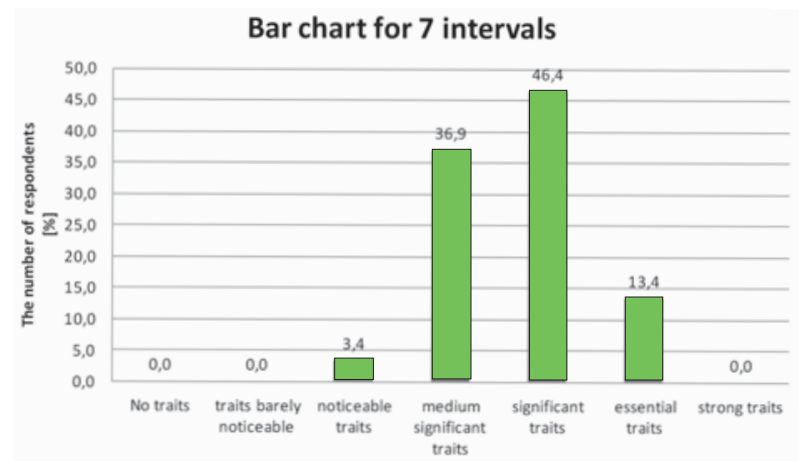

Figure 2-Percentage distribution of surveyed workers according to variability intervals (individual study) 


\section{Employee attitudes to work safety in Poland's coal mining companies}

where

$d_{m}(x, \mu)$ is the Mahalanobis distance $i$ of the variable for $x$ employee

$x_{1}, \ldots x_{n}$ are the answers of respondents

$\mu_{1}, \ldots, \mu_{n}$ is the model,

Mahalanobis distance calculations were performed using the Matlab 7.1 program, in which a procedure for determining the degree of slavery of a surveyed worker in relation to the assumed model was implemented. The procedure was as follows:

for $\mathrm{i}=1: \mathrm{n}$,

$\mathrm{X}(:, \mathrm{i})=$ dane $(:, \mathrm{i})$-idea;

$\mathrm{C}(\mathrm{i})=\operatorname{cov}(\mathrm{X}(:, \mathrm{i}))$;

end

where:

the data table includes the survey responses

the idea table is the developed model

'cov' is the Matlab 7.1 function entered, illustrating the covariance of the 'data' and 'idea'.

\section{Results}

For individual variability intervals, employee attitudes towards OHS in the workplace, from the least intensified Ztype traits to the strongest ones, were characterized. Then, extreme intervals were compared to identify whether a Z-type worker displays a different attitude towards OHS than that of others. The research included the following issues:

> Has the professional adaptation process prepared you well for work in a safe environment?

> Are you personally responsible for following OHS regulations?

> Does your family's financial wellbeing depend on your career security?

- Does complying with OHS regulations make your work more difficult?

$>$ Would you breach OHS regulations in order to keep your job?

- Would you breach OHS regulations in order to make your work easier?

The attitudes of employee from the lowest to the highest intensity of Z-traits (from 'Noticeable traits' to 'Essential traits) are compared in Figures 3-6.

The results of the survey showed that $13.4 \%$ of the respondents showed a 'significant level' of Z-type worker attitudes (Figure 2). The attitudes of this group of employees can be summarized as follows (Figures 3-6).

> Employees with Z-type attitudes believed that they were well-prepared for professional work during the process of professional adaptation ( $96 \%$ of respondents)

- As many as $25 \%$ of individuals with such an attitude did not feel directly responsible for complying with OHS regulations

> $50 \%$ of individuals believed that the financial security of their families depends on their career security

> As many as $67 \%$ of respondents with the enslaved Ztype attitude expressed the opinion that complying with OHS regulations makes work more difficult

> $54 \%$ of respondents would breach OHS regulations to make their work easier.
The responses of workers who did not demonstrate any of the Z-type traits were completely different:

> Only $67 \%$ believed that they were prepared well to the professional work during the process of professional adaptation

group: `Noticeable traits`

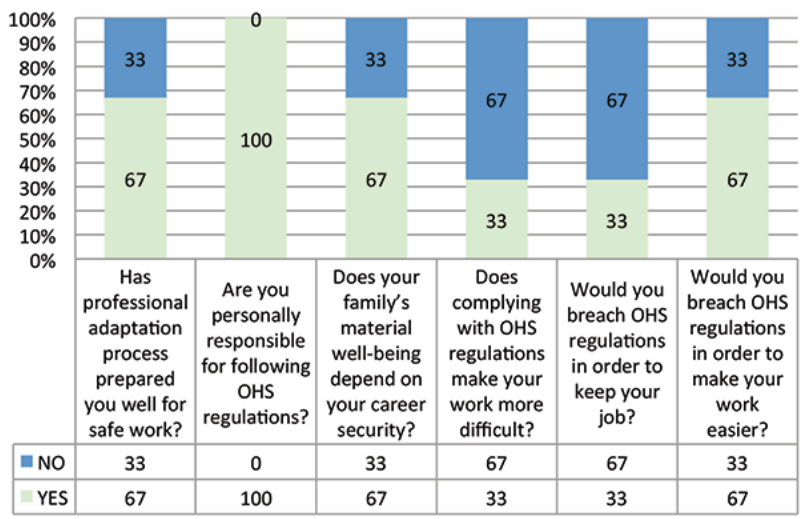

Figure 3-Variability ranges from 5.43 to 8.14 , Noticeable traits (individual study)

group: ‘Medium-significant traits`

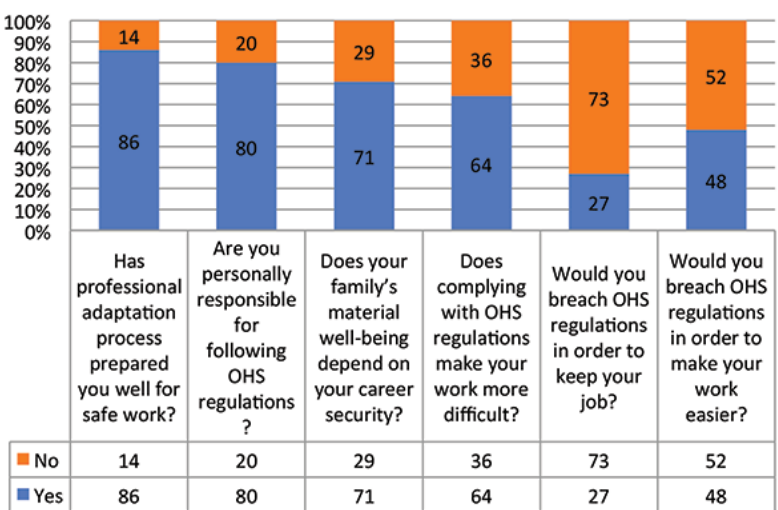

Figure 4-Variability ranges from 8.14 to 10.86 , Medium-significant traits (individual study)

group: 'Significant traits'

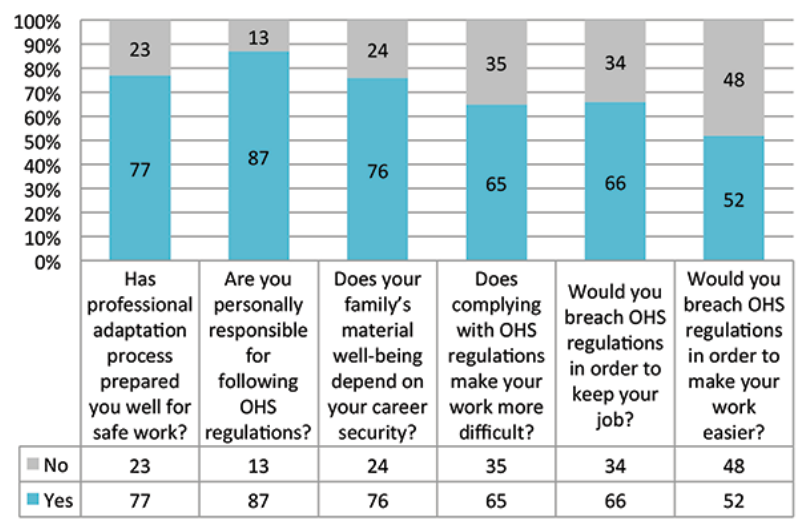

Figure 5-Variability ranges from 10.86 to 13.57 , Significant traits (individual study) 


\section{Employee attitudes to work safety in Poland's coal mining companies}

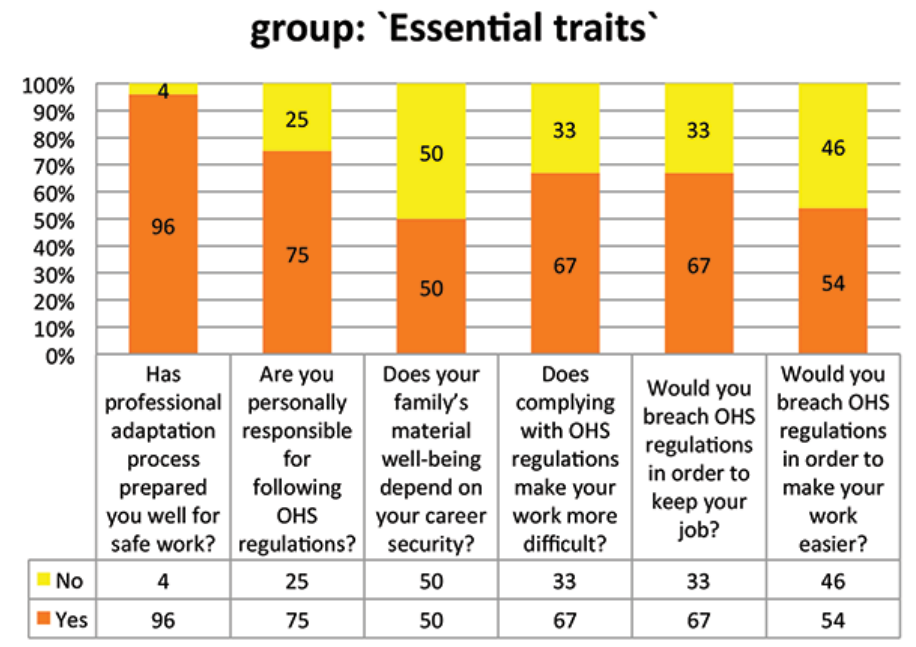

Figure 6-Variability ranges from 13.57 to 16.29 , Essential traits (individual study)

> $100 \%$ felt directly responsible for complying with OHS regulations

> $67 \%$ of individuals believed that the financial security of their families depends on their career security

> $67 \%$ of respondents were of the opinion that complying with OHS regulations does not make their work more difficult

> $67 \%$ of respondents would breach OHS regulations to make their work easier. These are individuals who are more strongly self-controlled.

The research showed a difference in attitude between employees with a strong intensity of Z-traits and other workers regarding compliance with OHS regulations and their perception of safety in the workplace. This encourages us to concentrate on developing motivational tools to control such workers so that they do not become a source of danger for their colleagues.

\section{Summary and conclusions}

The survey confirmed the occurrence of a significant (13.4\%) group of workers representing the ' $Z$ '-type attitude in the three mining companies, i.e. the passive-enslaved worker characterized at the beginning of the paper. The answers of respondents in this group indicated a relationship between Ztype behaviour and attitudes towards OHS regulations. This was confirmed by comparing the answers of surveyed enslaved workers with those from the respondents that did not present any traits of the Z-type 'enslaved' worker.

> A larger number of passive-enslaved individuals indicated that they had been well prepared for safe working during their professional adaptation

> An enslaved worker feels less direct responsibility for complying with OHS regulations (25\% fewer respondents) than other respondents

> $67 \%$ of workers without passive traits stated that complying with OHS regulations does not make their work more difficult

> $67 \%$ of passive workers stated that OHS regulations make their work harder, which certainly suggests that such workers would be less diligent in complying with and actively applying those regulations. This is a cause for concern, since such attitudes, if strongly displayed, could adversely affect compliance with OHS regulations in the entire community

> Z-type workers are willing to breach OHS regulations in order to keep their jobs.

The differences in attitudes between Z-type workers and the remaining respondents proves the necessity of studying the phenomenon and conducting further investigations in this field, especially in the area of recruitment (to eliminate such candidates), periodic evaluations, safety motivational programmes, analysis of causes of accidents, and $\mathrm{OHS}$ promotion.

On the basis of the characteristics of the Z-type attitude, we can state that a system of motivation for safe work should:

1. Rely on clearly specified principles of individual rewards and punishments, including all essential areas of activities

2. Precisely determine the range of duties for such workers and control their observance of OHS regulations strictly and consistently

3. Determine evaluation criteria clearly and objectively.

In this way we may eliminate the sense of injustice among workers so as not to strengthen Z-type attitudes. It is also worth emphasising that a Z-type ('passively active') worker (Tobór-Osadnik and Wyganowska, 2011) needs a strong, respected leader or superior, perhaps one displaying an authoritarian style of management.

The developed methodology of research and the original program written for this investigation allows research and experiments to be performed in any enterprise, automating the generation of results and reporting on the current state. The results obtained allow innovative motivational tools to be developed for those individuals displaying Z-type personality traits. The model presented also allows for periodic testing to detect any changes in employee behaviour. The generated model is so versatile that it can be adapted to any local occupational health and safety regulations. 


\section{Employee attitudes to work safety in Poland's coal mining companies}

\section{References}

Aczel, A. 2010. Statystyka w zarządzaniu (Statistics Management), Polish Scientific Publishers, Warsaw. pp. 24-28.

BLANCHARD, K.H. 2007. Przywództwo wyższego stopnia, (Leading at a higher level), Polish Scientific Publishers, Warsaw. pp. 76-80.

Coutu, D.L. 2002. How resilience works. Harvard Business Review, vol. 80. pp. $46-55$.

Douglas, S.C. and MarTinKo, M.J. 2001. Exploring the role of individual differences in the prediction of workplace aggression. Journal of Applied Psychology, 86. pp. 547-559.

Gabryelewicz, I., SAdŁowska-WrzesińSka, J., and Kowal, A. 2015. Koncepcja ankietowego badania poziomu kultury bezpieczeństwa (A conception of an application aiding the assessment of a safety culture level in a company) [w] red. R. Knosala: Innowacje w zarządzaniu i inżynierii produkcji (Innovation in management and production engineering)., Oficyna Wydawnicza Polskiego Towarzystwa Zarządzania Produkcją (Publishing House of the Polish Society for Production Management) Opole. pp. 396-406.

HaRvey, P. and Martinko, M.J. 2009. Attribution theory and motivation. Organizational Behavior, Theory, and Design in Health Care. Borkowski, N. (red.). Jones \& Bartlett Learning, Burlington, MA. pp. 147-164.

KoRAcH, R. 2009. Nagroda i kara. Profesjonalna ocena pracownika (Reward and punishment. Professional staff assessment), Helion Publishers, Gliwice. pp. 238.

LIs, T. and Nowacki, K. 2005. Zarządzanie bezpieczeństwem i higieną pracy w zakładzie przemysłowym (Management of occupational health and safety in the industrial plant), Silesian University of Technology Press, Gliwice. pp. 11.

MAcey, W.H. and Schneider, B. 2008. The meaning of employee engagement. Industrial and Organizational Psychology, vol. 1. pp. 3-30.

Martinko, M.J., Douglas, S.C., Harvey, P., and Joseph, C. 2005. Managing organizational deviance, Sage, Thousand Oaks, CA. pp. 237-260.

MARTYKA, J. 2013. Stan podstawowych elementów kultury bezpieczeństwa osób dozoru ruchu w wybranych kopalniach węgla kamiennego (State of the basic elements of the safety culture of traffic supervisory workers in the selected coal mines). Przegląd Górniczy (Polish Mining Review), no. 3. pp. 85-92.

MoczYDŁowsKA, J. 2005. Wyuczona bezradność - psychologiczna bariera w ograniczaniu nierówności społecznych (Acquired Helplessness - a Psychological Barrier to Reducing Social Inequalities). [w] Woźniak M.G.(red.): Kapitat Ludzki i Intelektualny, University of Rzeszów Press Rzeszów. pp. 419-426.

Muethel, M. and HoEgl, M. 2010. Cultural and societal influences on shared leadership in globally dispersed teams. Journal of International Management, vol. 16, no. 3. pp. 234-246.

NAjMiec, A. and MilczAREK, M. 2003. Indywidualne uwarunkowania bezpiecznych zachowań pracowników (Individual determinants workers' safe behaviors), Bezpieczeństwo Pracy (Ocupation Safety. Science and Practic) 6. pp. 5.

OchinowsKi, T. and GrZYwACZ, W. 2003. Kult korporacyjny-zwyrodnienie relacji między firma a pracownikami (The Corporate Cult : Degeneration of the Employee-Company Relationship). Zarządzanie Zasobami Ludzkimi
(Human Resource Management) Nr 2, Institute of Labour and Social Studies, Warsaw. pp. 69-76.

PRzenniah, W. 2007. Motywowanie pracowników do bezpiecznych zachowań kluczowy czynnik w realizacji procesu zarządzania bezpieczeństwem [w] Lachniewicz, S., Matejuna, M. Problemy Wspótczesnej Praktyki Zarządzania (Problems of modern management practices), tom.1., Lodz University of Technology Press, Łódź. pp. 313-323.

SADŁoWSKA-WrZESIŃSKA, J. 2014. Kultura bezpieczeństwa pracy jako element silnej kultury organizacyjnej (Culture of safety as a part of a strong organizational culture), [w]: Bezpieczeństwo i Prawa Człowieka w Badaniach Młodych Naukowców (Security and human rights in the research of young scientists), Dziemianko, Z. and Stach, W. (Red.), Publisher Poznań University Of Commerce And Services, Poznań. pp. 287-296.

Schwarz, G. 2010. Estimating the dimension of a model. Annals of Statistics, vol. 6, no. 2. pp. 461-464.

StAnISŁAWEK, J. 2010. Podstawy statystyki (Fundamentals of Statistics), Warsaw University Press, Warsaw. pp. 26.

StARZYŃSKA, W. (ed.). 2009. Podstawy statystyki (Fundamentals of Statistics) Difin, Warsaw. pp. 52-66.

Studenski, R. 1996. Organizacja Bezpiecznej Pracy w Przedsiębiorstwie (The organization of Work Safety In the Enterprise). Silesian University of Technology Press, Gliwice. pp. 38-43.

STUDENSKI, R. 2000. Kultura bezpieczeństwa pracy w przedsiębiorstwie (Culture of safety in the company). Occupation Safety. Science and Practic, Central Institute for Labour Protection, Warsaw, no 9. pp. 1-4.

SzczygielsKA, A. and WrZesińsKA, J. 2009. Kształtowanie pozytywnej postawy pracowników wobec bezpieczeństwa pracy (Shaping worker's positive attitude towards work safety). Occupation Safety. Science and Practic, Central Institute for Labour Protection, Warsaw, no 12. pp. 16-19.

SzUBIELSKA, J. 2011. Zarządzanie a kultura bezpieczeństwa w kopalniach węgla kamiennego (Management vs. culture of safety in coal mines). Wiadomości Górnicze, no 5. pp. 252-258.

ToвóR-OsadniK, K. and WyganowsKa, M. 2011. Identyfikacja postaw pracowniczych (Identification of employee attitudes). Wiadomości Górnicze, no 3. pp. $155-161$.

ToBóR-OsadniK, K. and WyganowsKa, M. 2012. Postawy wobec bezpieczeństwa pracy i bezpieczeństwa zatrudnienia w polskich przedsiębiorstwach górniczych węgla kamiennego (Attitudes towards security and security of employment in the Polish coal mining enterprises). Wiadomości Górnicze no. 10 . pp. $578-585$.

ToвóR-Osadnk, K. 2012. Identyfikacja Postaw Pracowniczych w Różnych Kulturach Technicznych na Przykładzie Przedsiębiorstwa Górniczego. (Identification of 'workers` attitudes In various technical cultures on the example of mining company), Silesian University of Technology Press, Gliwice. pp. 10-25.

ToBóR-OSADniK, K., KABALski, P., and WyganowsKa, M. 2013. International financial reporting standards $v s$. homo sovieticus personality - the case of Poland. International Journal of Business and Social Research, vol. 3 , no. 6. pp. 17-35.

YILDIZ, E.H. 2014. Not all differences are the same: dual roles of status and cultural distance in sociocultural integration in cross-border $M \& A s$. Journal of International Management, vol. 20, no. 1. pp. 25-37. 